\title{
Physiological performance of cagaita seeds (Eugenia dysenterica DC.) Subjected to drying ${ }^{1}$
}

\author{
Desempenho fisiológico de sementes de cagaita \\ (Eugenia dysenterica DC.) Submetidas à secagem
}

\author{
Lílian Abadia da Silva ${ }^{2 *}$; Juliana de Fátima Sales ${ }^{3}$; Heloísa Oliveira dos Santos ${ }^{4}$; \\ Juliana Montazola Martins' ${ }^{2}$; Valéria Hanny Costa ${ }^{5}$; Fabiano Guimarães Silva ${ }^{3}$
}

\begin{abstract}
The present study aimed to determine the imbibition curve and evaluate the effects of 'reducing the water content of cagaita seeds (Eugenia dysenterica DC.), using the radiographic image analysis technique. To this end, three assays were carried out: seed imbibition curve and root protrusion were determined in assay 1 . Seeds in silica gel were oven dried for to $72 \mathrm{~h}$ and were then analyzed for water content and vigor in assay 2. Seeds were dried up to certain levels of the water content and were evaluated by radiographic imaging analysis in assay 3. A rapid mass gain was observed in the first 60 imbibition hours and the root protrusion reached $94.4 \%$ after 192 imbibition hours. Cagaita seeds did not tolerate drying periods longer than $24 \mathrm{~h}$, which corroborates the recalcitrant behavior of the seeds of these species. The analysis of the radiographic image obtained by an X-ray test allowed the establishment of a direct relation between the increased free space area within the seed and the decrease in the seedling emergence. The drying process altered the internal morphology of the seed and such changes directly influenced the development of the seedlings.
\end{abstract}

Key words: Native fruit. Myrtaceae. Drying. Recalcitrant. X-ray test.

\section{Resumo}

Objetivou-se com este trabalho determinar as relações entre níveis de absorção de água e a germinação, bem como, avaliar os efeitos da redução do teor de água no vigor de sementes de cagaita (Eugenia dysenterica DC.). Para tanto, foram realizados três ensaios: No ensaio 1 determinou-se a curva de embebição e germinação das sementes. No ensaio 2 as sementes foram submetidas a secagem em estufa e em sílica gel por até 72 horas e submetidas a avaliações do teor de água e do vigor. No ensaio 3 as sementes foram submetidas a secagem até determinados teores de água e avaliadas por meio da análise de imagens radiográficas. Houve um rápido ganho de massa nas primeiras 60 horas de embebição, com protrusão radicular chegando a 94,4\% após 192 horas de embebição. As sementes de cagaita não toleraram secagem por períodos superiores a 24 horas, reafirmando o comportamento recalcitrante das sementes da espécie. A partir da análise de imagens radiográficas, obtidas pelo teste de Raios X, foi possível estabelecer relação direta entre o aumento da área de espaço livre no interior da semente, e a diminuição da emergência de plântulas.

Palavras-chave: Frutífera nativa. Myrtaceae. Secagem. Recalcitrante. Teste de raios X.

${ }^{1}$ Parte da Tese de Doutorado do primeiro autor.

2 Discentes, Programa de Pós-Graduação em Ciências Agrárias, PPGCA-Agronomia, Instituto Federal de Educação, Ciência e Tecnologia Goiano, IFGoiano, Rio Verde, GO, Brasil. E-mail: lilianabadia5@gmail.com; julianamontazolamartins@gmail.com

3 Profs., Programa de Pós-Graduação em Ciências Agrárias, PPGCA-Agronomia, Instituto Federal de Educação, Ciência e Tecnologia Goiano, IFGoiano, Rio Verde, GO, Brasil. E-mail: juliana.sales@ifgoiano.edu.br; fabianoifgoiano@gmail.com

${ }^{4}$ Prof $^{\mathrm{a}}$, Departamento de Agricultura, Setor de Sementes, Universidade Federal de Lavras, UFLA, Lavras, MG, Brasil. E-mail: heloisa.ufs@gmail.com

5 Discente, Curso de Agronomia, Departamento de Agricultura, Setor de Sementes, Universidade Federal de Lavras, UFLA, Lavras, MG, Brasil. E-mail: val_hanny@hotmail.com

* Author for correspondence 


\section{Introduction}

The Brazilian territory is substantially covered by different medicinal and fruit species distributed in different ecosystems. It is estimated that the Brazilian Cerrado contains 10,000 plant species of the 60,000 phanerogams distributed across the country, and it features the richest flora among the savannas worldwide (GUSMÃO et al., 2006). In addition, the Cerrado is considered one of the hotspots for global biodiversity conservation, and many of the species found in it are known to be sources of biotechnological compounds of interest to applications in the medical and food industries (CARAMORI et al., 2004; KLINK; MACHADO, 2005).

Cagaita (Eugenia dysenterica DC.), which is a species that belongs to the family Myrtaceae is distinctive among the native fruit species found in the Cerrado domain. This arboreal species can reach up to 10 meters high and exhibits crooked branches as well as a thick and fissured bark. It also presents yellowish bacaceous fruits that are globose in shape when they are ripe. On an average, each fruit contains one to three seeds corresponding to $15 \%$ of the fruit's mass. Cagaita is considered a species of economic interest, and its fruits are consumed fresh or processed as juices, jams, jellies, and ice cream. Cagaita fruits exhibit physical and chemical features that meet industrialization potentials. Their high acidity, low caloric values, and low lipid and carbohydrate levels renders the exploitation of these fruits a promising economic activity. The species also stands out for its medicinal properties, since its fruits, leaves, and bark are used to treat diarrhea, diabetes, and jaundice. In addition, cagaita is indicated as a melliferous and ornamental plant and it may also be grown in the degraded areas for reforestation (CAMILO et al., 2014; MARTINOTTO et al., 2008; SILVA et al., 2001; VIEIRA et al., 2010).

The seeds of species of the genus Eugenia are in general classified as intolerant to desiccation, and their conservation demands high moisture levels (OLIVEIRA et al., 2011). Unlike the orthodox seeds, which acquire tolerance to desiccation during maturation, the recalcitrant seeds are unable to survive drying and hardly lose water during maturation. They directly proceed from developmental metabolism to germination (BARTELS, 2005; DELAHAIE et al., 2013; RADWAN et al., 2014).

The recalcitrant seed species are common in the tropical forests as these forests possess superior conditions for germination and seedling establishment due to their optimal temperature and rainfall conditions (PAMMENTER; BERJAK, 2000). Seeds from several desiccation-sensitive species lose their viability during drying. It is accompanied by increased lipid peroxidation, accumulation of free radicals, and by destabilization or loss of macromolecular integrity. Recent studies highlight that LEA (late embryogenesis abundant) proteins, which are synthesized by the orthodox seeds during the final maturation phase and are essential for desiccation tolerance, are not synthesized by the desiccation-sensitive seeds (AMARA et al., 2012; BOUDET et al., 2006; DELAHAIE et al., 2013). In addition, several other mechanisms that enable desiccation tolerance are absent in the recalcitrant seeds (BERJAK; PAMMENTER, 2013).

Morphological changes may occur and affect the seed quality and viability during the drying process. The embryonic area, which consists the relationship between the degree of embryo development and the available space within the internal cavity of the seed, is one of the morphological variations possibly associated with seed performance. This feature has been evaluated by X-ray image analysis (MARCOS FILHO et al., 2010; MACHADO; CICERO, 2003).

Forest species are characterized by a high incidence of predation, empty seeds, and embryo malformation, among others. Thus, the X-ray test is a useful tool to assess the physical quality of seeds. This tool has been used in quality control 
programs and it may also assist morphological and physiological studies of several species (MASETTO et al., 2007). It is a precision method that allows a thorough examination of the internal morphology of seeds (BINO et al., 1993). In addition, the seed analysis by the X-ray technique allows the selection of undamaged seeds in order to form higher quality lots that aid seed conservation in germplasm banks (CARVALHO et al., 2009).

Therefore, the present study was conducted to determine the imbibition curve, evaluate the effects of reducing the water content of cagaita seeds ( $E$. dysenterica DC.) using the radiographic image analysis technique.

\section{Materials and Methods}

The study was conducted at the Seed Laboratory of the Federal Institute of Goiás, Campus Rio Verde (GO), and the Seed Analysis Laboratory of the Agriculture Department - Federal University of Lavras (Lavras-MG, Brazil). The ripe fruits (with completely yellow epicarp) were harvested from Fazenda Gameleira ( $16^{\circ} 06^{\prime} 20$ ' S latitude $-51^{\circ}$ 17 ' 11 "W longitude, $592 \mathrm{~m}$ altitude) in the Montes Claros de Goiás County (Goias, Brazil). The harvest comprised of approximately eight matrix trees close to each other. The pulping process was carried out by manually macerating the fruits on sieves and seeds were obtained by washing under running water until the pulp residues were eliminated. After pulping, the seeds were processed and the damaged ones were discarded. The undamaged seeds were superficially sterilized in 5\% sodium hypochlorite commercial solution for three minutes, washed again with distilled water, and placed in trays covered by paper towels at room temperature in order to remove the excess surface water.

The study involved three assays:
Assay 1. Imbibition curve and root protrusion of $E$. dysenterica seeds

The relationship between the seed imbibition speed and root protrusion was investigated in this assay. Four replicates of 25 seeds with harvesting water content at $48.0 \%$ (w.b.) were tested to obtain the imbibition curve. The samples were weighed on a $0.001 \mathrm{~g}$ precision scale to determine their initial mass. The seeds were then sown on "germitest" paper sheets moistened with distilled water in amounts equivalent to 2.5 times the weight of the dry substrate (BRASIL, 2009). They were then maintained in the germination chamber at $30{ }^{\circ} \mathrm{C}$. The seed mass from each replicate was assessed every $3 \mathrm{~h}$ in the first 12 imbibition hours followed by that at every $12 \mathrm{~h}$ up to 192 imbibition hours. Seeds were removed from the substrate using tweezers for the assessment at every imbibition time. They were weighed and arranged on the substrate as described previously. The seed mass gain was calculated according to the following formula:

$$
W g=\frac{F w-I w}{I w} \times 100
$$

$W g$ : mass gain seeds; Fw: Final weight (moisture gain at every imbibition period); $I w$ : initial seed weight before imbibition.

The root protrusion percentage was evaluated at every imbibition time in order to establish the relationship between the times required for the seeds' root protrusion, by considering the seeds with $0.5 \mathrm{~cm}$ length of germinated primary root.

Assay 2. Effect of drying on seed vigor and the initial growth of E. dysenterica seedlings

The initial water content of the seeds was determined in 4 subsamples of 10 seeds, before drying the seeds by the oven method at $105 \pm 3^{\circ} \mathrm{C}$ for $24 \mathrm{~h}$ (BRASIL, 2009). The result was expressed as wet basis percentage (\% w.b.). 
After the initial water content was determined, seed samples were used to evaluate the drying time at zero hours (control treatment with initial water content), and the remaining seeds were subjected to two types of drying: Drying in silica gel, in which the seeds were in direct contact with a uniform silica gel layer. They were placed in hermetically closed plastic trays maintained at $25 \pm 3{ }^{\circ} \mathrm{C}$, and the silica gel was replaced every time its most superficial layer $(2 \mathrm{~cm})$ lost its intense blue color; Oven-drying with air circulation and renewal, set at $35 \pm 2{ }^{\circ} \mathrm{C}$ temperature. The seeds were placed in craft paper bags and subjected to drying for 12, 24, 48, and $72 \mathrm{~h}$. Seed samples were obtained during every drying period in order to evaluate the following parameters: seed water content, respiratory rate, seedling emergence, seedling emergence speed index, seedling length, number of leaves, and seedling shoot and root dry mass.

1. Water content: The seed water content was determined after each drying period by the oven method at $105 \pm 3{ }^{\circ} \mathrm{C}$ for $24 \mathrm{~h}$ (BRASIL, 2009), using 4 subsamples of 10 seeds in each drying period. The results were expressed as percentage of wet basis (\% w.b.).

2. Electrical conductivity test: It was carried out using 4 subsamples of 15 seeds per treatment. The seeds were weighed to an accuracy of two decimal places and were then placed in plastic cups with $75 \mathrm{~mL}$ deionized water. After 24 imbibition hours in B.O.D (Biochemical oxygen demand) at $25^{\circ} \mathrm{C}$, the electrical conductivity was determined using a digital conductivity meter (Tecnal TEC-4MP Model) and the results were expressed in $\mu{\mathrm{S} . \mathrm{cm}^{-1}}^{-}$. $\mathrm{g}^{-1}$, according to the method described by Vieira (1994).

3. Respiratory rate: It was determined by the titration method according to the methodology described by Crispim et al. (1994). Four subsamples of 15 seeds were used, and they were pre-weighed to obtain the dry weight. The bottom of each germination box was soaked in $40 \mathrm{~mL} 0.1 \mathrm{~N} \mathrm{KOH}$ solution and two sheets of blotting paper moistened with distilled water at amounts that was 2.5 times the dry weight and were placed on the canvas. Seeds were distributed on the blotting papers in an even layer. Each sample contained a control called blank, which was prepared without seeds. After being maintained for $24 \mathrm{~h}$ at a constant temperature of 30 ${ }^{\circ} \mathrm{C}, 25 \mathrm{~mL}$ of $0.1 \mathrm{~N} \mathrm{KOH}$ solution was removed from each replicate and three drops of phenolphthalein was added for titration with $0.1 \mathrm{~N} \mathrm{HCl}$. The $\mathrm{HCl}$ volume required to neutralize the $\mathrm{KOH}$ solution in each of the tested samples was recorded at the turning point. The respiratory rate was calculated according to the following equation:

$$
R R=\frac{(B-R) x C}{D M}
$$

Wherein: $B$ is the blank reading; $R$ is the titration reading using $\mathrm{HCl}$; $C$ is the constant called the correction factor with value of 3.52 , and $D M$ is the dry mass of seeds submitted to evaluations. The results were expressed in $\mathrm{mg}$ of $\mathrm{CO}_{2}$ per gram of dry seed.

4. Emergence Test: It was conducted in a greenhouse at a mean temperature of $28.9 \pm 4{ }^{\circ} \mathrm{C}$ and a relative humidity of $76 \pm 4.5 \%$ during the evaluations. Four replicates of 25 seeds were used and the seeds were sown in the sand at a depth of 3 $\mathrm{cm}$. The substrate was irrigated three times a day by sprinkling for $30 \mathrm{~min}$. Daily counts were performed by recording the seedling emergence above $1.5 \mathrm{~cm}$ in order to determine the seedling emergence speed index (ESI), according to the method described by Maguire (1962). Forty-five days after sowing, the emergence percentage corresponded to that of the normal seedlings (with all the essential structures already formed and without any damage). The seedling length was measured in the normal seedlings from the emergence test employing a centimeter ruler, and the results were expressed in $\mathrm{cm} /$ seedling. Ten normal seedlings from each replicate were randomly separated for the shoot and roots, placed in paper bags, and subjected to 
oven drying with an air circulation at $65{ }^{\circ} \mathrm{C}$ for $72 \mathrm{~h}$, in order to determine the shoot and root dry mass. After drying, the samples were weighed on a 0.0001 precision electronic scale and the results were expressed in $\mathrm{g} /$ seedlings.

The experimental design was completely randomized in a $2 \times 5$ factorial design in four replicates, applying two types of drying (silica and greenhouse) for five times $(0,12,24,48$, and $72 \mathrm{~h})$. The data were subjected to variance analysis at $5 \%$ probability and to polynomial regression analysis using Sisvar software (Variance Analysis System) for Windows (FERREIRA, 2003). The polynomial regressions were adjusted using Sigma Plot ${ }^{\circledR} 10.0$ software. The means were compared by Tukey's test at $5 \%$ probability.

Assay 3. Radiographic image analysis of E. dysenterica seeds subjected to drying

The initial water content of the seeds was set by the oven method at $105 \pm 3{ }^{\circ} \mathrm{C}$, for $24 \mathrm{~h}$ (BRASIL, 2009), as described in assay 2. After the initial water content $(47.8 \%)$ was determined, few of the seeds were subjected to slow drying in silica gel as established in assay 2, in order to obtain water contents of 37,28 , and $23 \%$. After drying, the seeds with different percentages of water content were subjected to the following evaluations:

The X-ray test was conducted at the Seed Analysis Laboratory of the Federal University of Lavras (MG). Four replicates of 20 seeds from each treatment were arranged on a double-sided adhesive tape placed on transparent acrylic plates and subjected to radiation at an intensity of $30 \mathrm{kV}$ for $45 \mathrm{~s}$ in "Faxitron HP" X-ray equipment (Model 43855A), to obtain digital images of the inner structures of the seeds. After obtaining the images, the free space area within the seed was calculated using the Tomato Analyzer 3.0 software, in which the area occupied by the embryo was defined and the free area percentage within each seed was expressed.

The emergence test was performed with 4 replicates of 20 seeds from each treatment, which were sown in the sand at $3 \mathrm{~cm}$ depth, irrigated by sprinkling 3 times a day. Forty-five days after sowing, the emergence percentage corresponded to that of normal seedlings.

The free area and emergence percentage data were subjected to variance analysis and to polynomial regression analysis. The correlation test between the variables was conducted and the significance of r-values was determined by t-test at $5 \%$ probability, using the ASSISTAT software.

\section{Results and Discussion}

Assay 1. Imbibition curve and root protrusion of $E$. dysenterica seeds

The seeds appeared swelled, increased in size, and changed in color during the early imbibition hours. The root protrusion could be observed from the 60 hour of imbibition (Figure 1).

Figure 1. E. dysenterica DC. seeds germination process throughout 192 hours of imbibition.

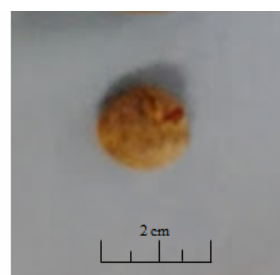

o hours

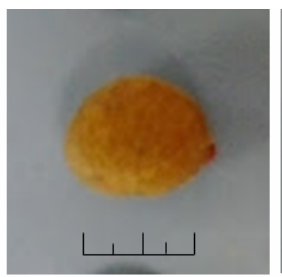

120 hours

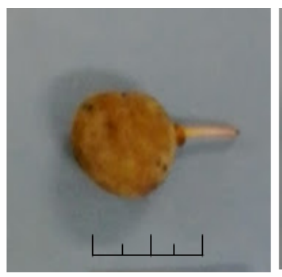

168 hours

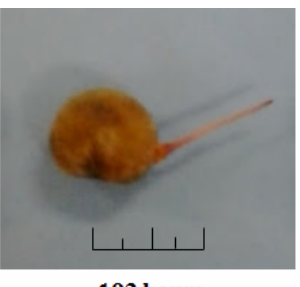

192 hours 
The E. dysenterica seeds with $38.36 \%$ water content were collected. The imbibition curve of cagaita seeds did not exhibit the classic three-phase pattern commonly observed in most species during the imbibition period (Figure 2). A rapid absorption of water was observed in the first $60 \mathrm{~h}$. After 120 imbibition hours, it reached the maximum value with
$11.04 \%$ increase in comparison to that of the seeds initial weight. After this period, water absorption remained stable. The root protrusion percentage of seeds linearly increased in response to the increase in the imbibition time, with a maximum value of 94.4 after 192 imbibition hours.

Figure 2. Water absorption (\%) based on fresh matter weight (g) and root protrusion (\%) of E. dysenterica DC. seeds during imbibition. * Significant at $5 \%$ probability $(\mathrm{p}<0.05)$. Bar: Mean standard error.

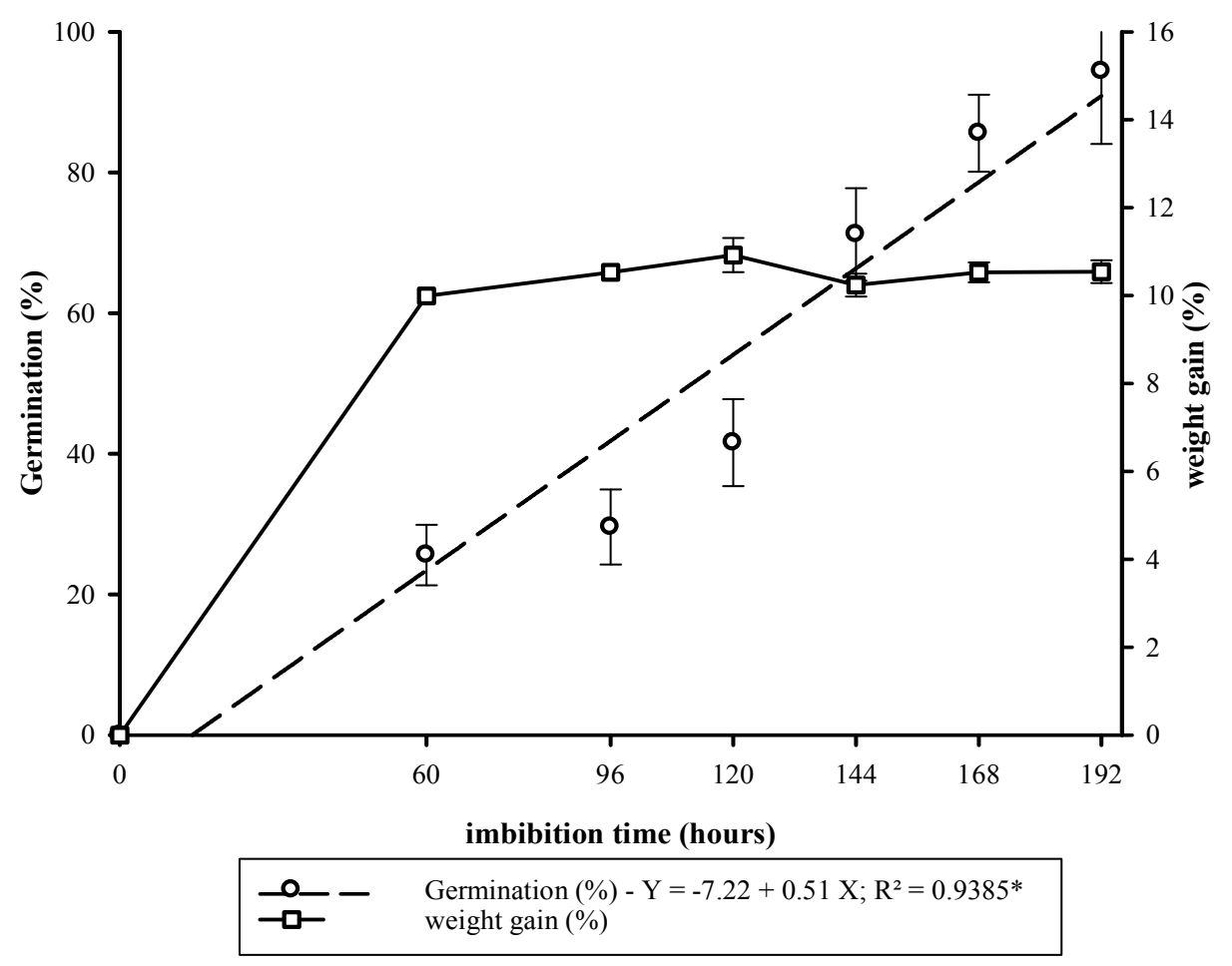

Dantas et al. (2008b) reported a similar result for the imbibition of the baraúna (Schinopsis brasiliensis Engl.) seeds. According to their results, $12.5 \%$ of the seeds visibly exhibited the growth of the embryonic axis after 152 imbibition hours. In contrast, the water absorption in the dedaleiro seeds (Lafoensia pacari A. St. Hil.) was progressive over five hours, and it resulted in a $90 \%$ increase in the seed weight after six hours of imbibition (FERNANDES et al., 2012). Catingueira seeds (Caesalpinia pyramidalis Tul.) exhibited rapid water absorption after $48 \mathrm{~h}$ of imbibition. After $54 \mathrm{~h}$, the radicle protrusion was
$10 \%$ and approximately a $76 \%$ increase in the initial weight was observed (DANTAS et al., 2008a).

Assay 2. Effect of drying on seed vigor and the initial growth of E. dysenterica seedlings

E. dysenterica seeds with $38.32 \%$ water content were collected. A linear decrease in this value in response to an increase in drying time was observed irrespective of the type of drying method employed. However, the water loss process was slow, since the water content remained at $38.05 \%$ after drying 
for $24 \mathrm{~h}$ (Figure 3) and it reduced to $37.22 \%$ at the of their initial condition irrespective of the type of end of $72 \mathrm{~h}$. After this period, the water content of drying method employed.

the seeds reduced by $0.83 \%$ in comparison to that

Figure 3. Water content of cagaita (Eugenia dysenterica DC.) seeds subjected to different drying periods. * Significant at $5 \%$ probability $(\mathrm{p}<0.05)$. Bar: Mean standard error.

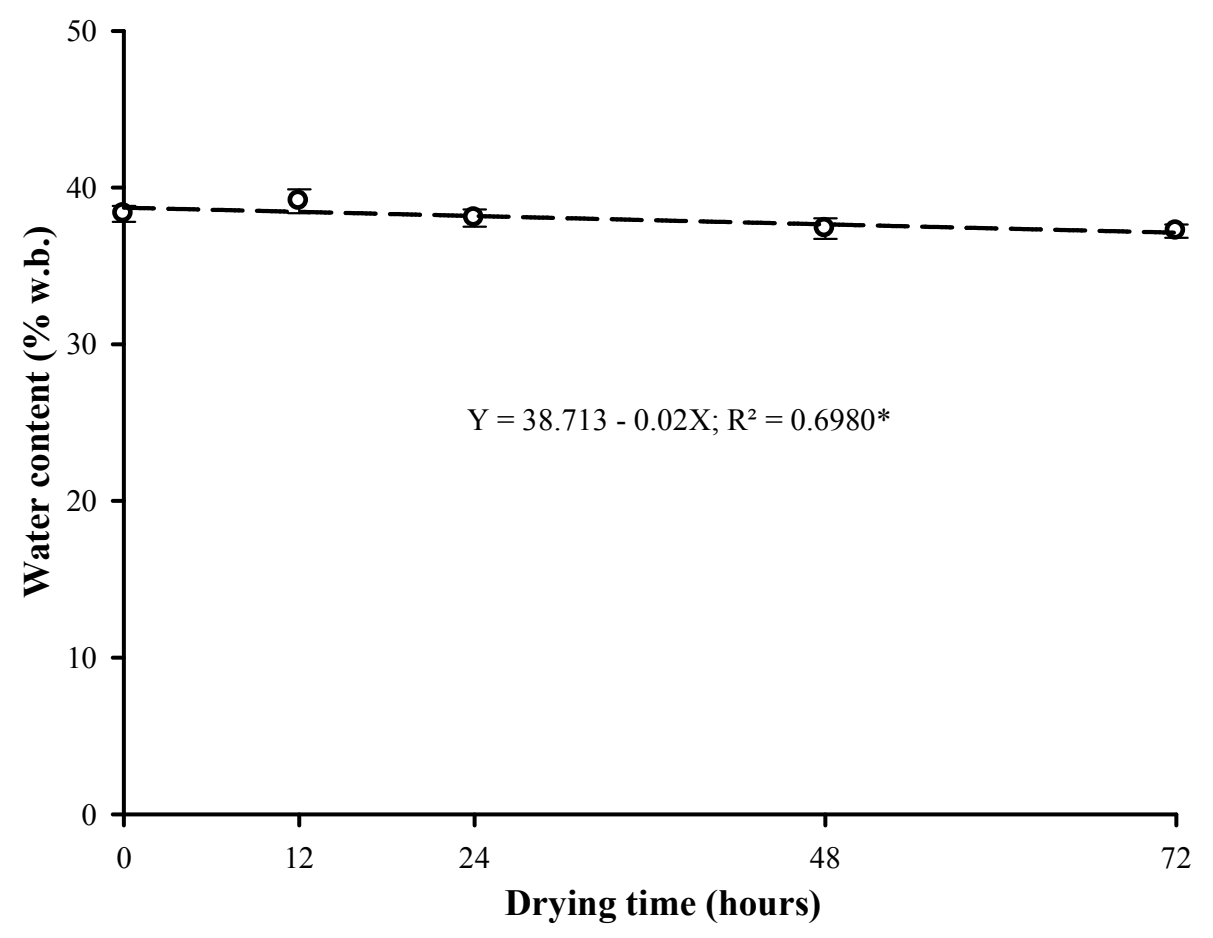

Andrade et al. (2003) conducted a study on E. dysenterica seeds collected from the Brasilia National Park. These seeds exhibited a high water content ranging between 47 and $53 \%$ at the sampling time. The seed drying rate at $24{ }^{\circ} \mathrm{C}$ and $15 \%$ relative humidity was higher than that obtained in the silica gel drying method at $15{ }^{\circ} \mathrm{C}$, thus approaching less than $20 \%$ water content in 28 days of drying. These results corroborate the slow water loss in the seeds from this species during the drying process as they require approximately 28 days for attaining 20\% water content. This behavior was also observed in seeds from other species of the genus Eugenia, as reported by Justo et al. (2007) such as the uvaia seeds (Eugenia pyriformis Camb.). The water content of these seeds was slightly reduced in milder drying treatments ( 16 and $72 \mathrm{~h}$ at $20^{\circ} \mathrm{C}$ and $16 \mathrm{~h}$ at $35^{\circ} \mathrm{C}$ ) in comparison to that of the initial water content. In addition, a higher water loss was observed during the drying at $35{ }^{\circ} \mathrm{C}$ for $72 \mathrm{~h}$, in which the seeds reached $30 \%$ water content with a $20 \%$ decrease based on the initial water content (50\%).

The type of drying did not influence the release of exudates as indicated by the electrical conductivity test. An increase in the electrical conductivity and water imbibition values was observed in response to the increase in the drying time (Figure 4).

The rate of exudation stabilized after $24 \mathrm{~h}$ of drying and reached a maximum value of 30.11 $\mu \mathrm{S} . \mathrm{cm}^{-1} \cdot \mathrm{g}^{-1}$ after $72 \mathrm{~h}$. Thus, the reduction in the water content negatively affected the cagaita seed vigor, despite the different types of drying methods used. The release of increased amounts of leachates 
by the seeds in response to the drying time indicates the damages in the cell membranes due to the drying process, which allows the release of ions from the cell solution to the imbibition solution. The disruption in the membrane system resulted in the loss of its semi-permeability and it led to the leaching of essential components of metabolism, thus marking the beginning of the deterioration process in the seeds (GOLOVINA et al., 2010; SANTOS et al., 2005).

Figure 4. Electrical conductivity of cagaita (Eugenia dysenterica DC.) seeds subjected to different drying periods. * Significant at $5 \%$ probability $(\mathrm{p}<0.05)$. Bar: Mean standard error.

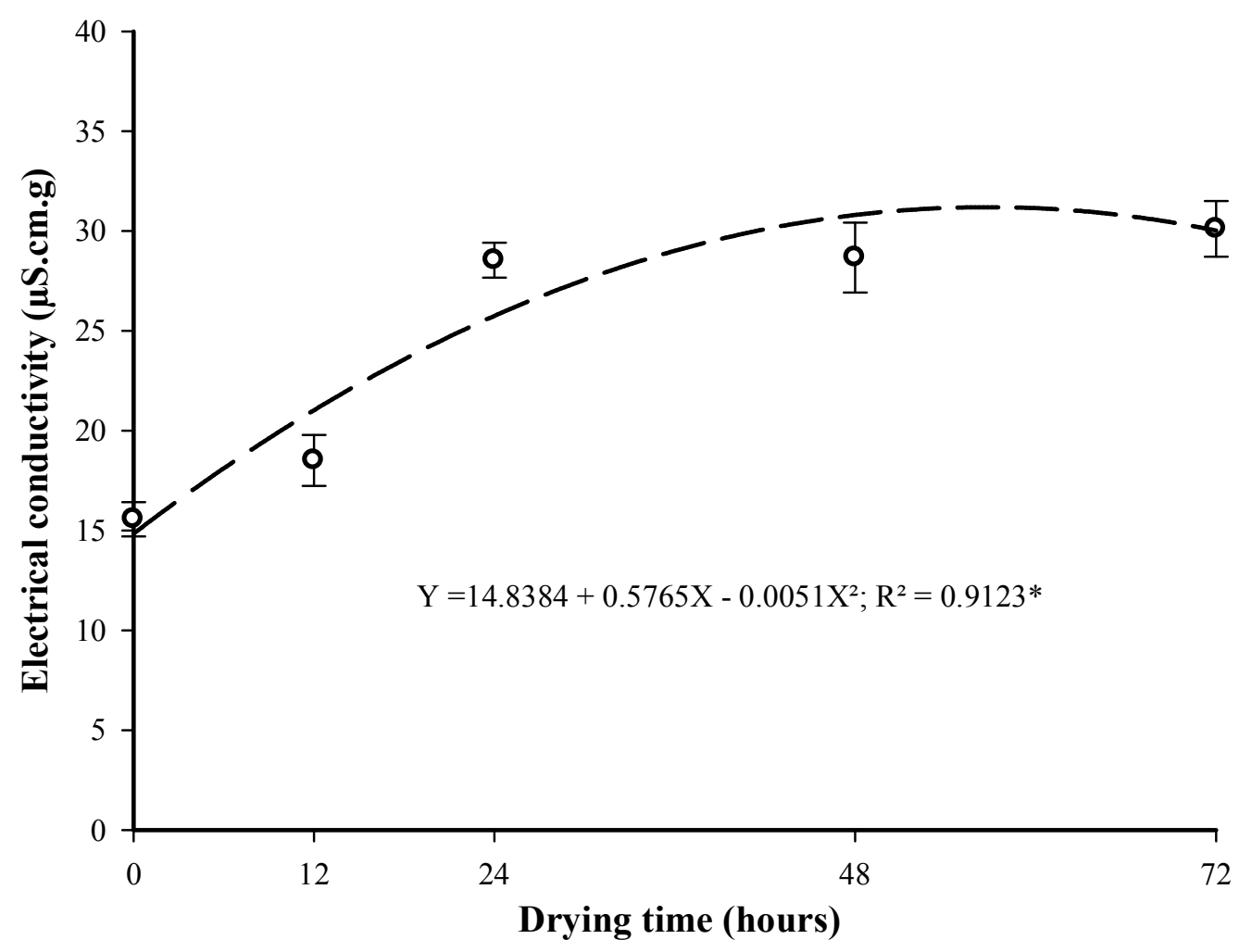

A linear increase was observed in the respiratory rate during the silica drying process, reaching a maximum value of $1.23 \mathrm{mg}$ of $\mathrm{CO}_{2}$ per gram of seed after $72 \mathrm{~h}$ with a 0.0068 increment in the response to the increased drying period. A minor increase in the respiratory rate was observed in the oven drying method between 12 and $24 \mathrm{~h}$ of drying; however, the respiratory rate decreased again after this period (Figure 5). 
Figure 5. Respiratory rate of E. dysenterica DC. seed subjected to different drying periods. *Significant at $5 \%$ probability $(\mathrm{p}<0.05)$. Bar: Mean standard error.

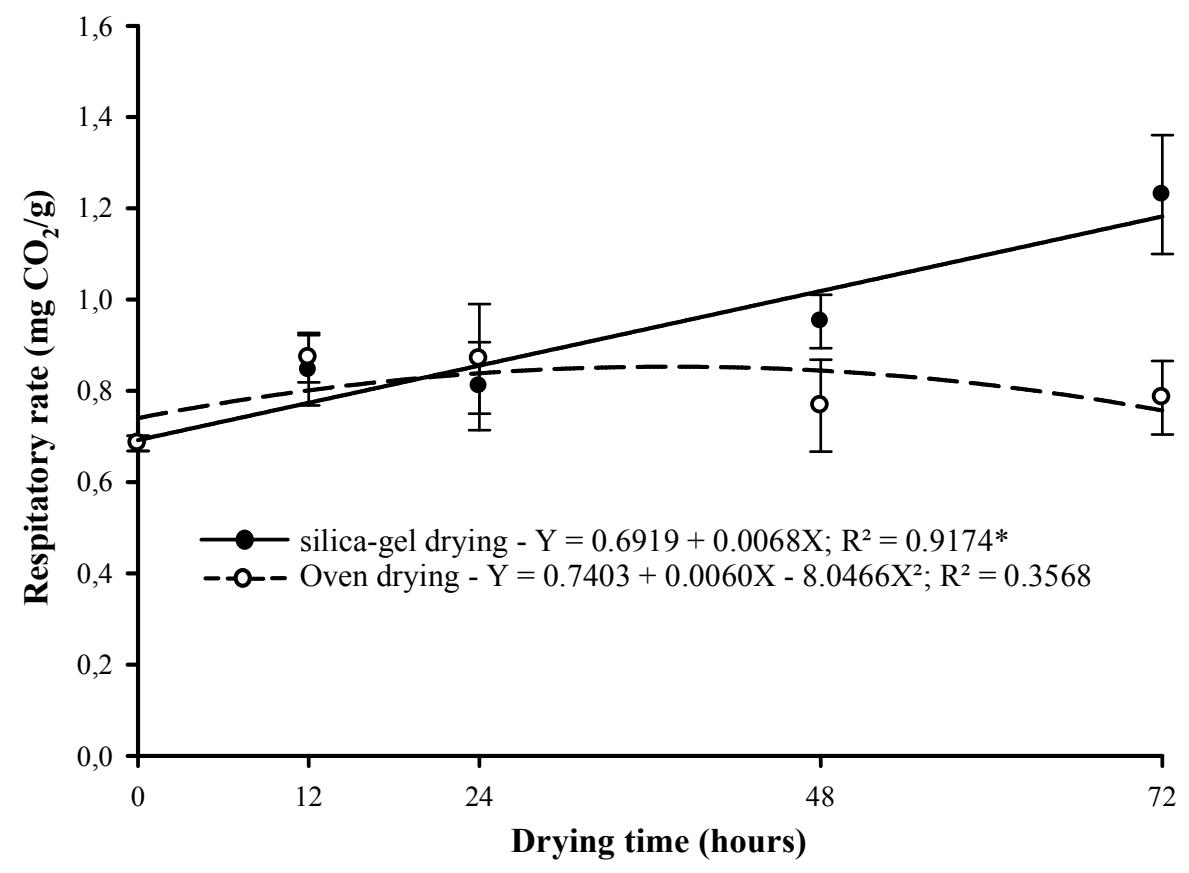

Silica gel drying is most suitable for E. dysenterica seeds as it positively influences the respiratory rate. Delgado and Barbedo (2007) observed that although the oven drying of seeds accelerated the drying speed, it might lead to changes in the seeds especially the enzymatic ones, which cause damages and accelerate the deterioration process.

The type of drying did not influence the percentage of seedling emergence. A quadratic behavior was observed wherein the seedling emergence increased during the first drying periods, thus reaching a maximum value of $63 \%$ after approximately $33 \mathrm{~h}$. As the drying period progressed, the seedling emergence decreased and it exhibited a negative effect of water content reduction on the physiological performance of the seeds of this species that confirmed their recalcitrant behavior (Figure 6).

These results corroborate those obtained by Andrade et al. (2003), according to whom E. dysenterica seeds exhibited 50\% germination rate when their water content was reduced to values between 36 and 38\%. The authors suggest that the seeds from this species completely lose viability when their water content is reduced to values below $18-22 \%$ (lethal water content) and they classified these seeds as sensitive to desiccation. Furthermore, the Brazilian cherry seeds (Eugenia uniflora L.) subjected to oven drying at $37{ }^{\circ} \mathrm{C}$ also lost viability during the first $14 \mathrm{~h}$ of drying and produced only $20 \%$ normal seedlings after $72 \mathrm{~h}$ (COMIN et al., 2014).

Delgado and Barbedo (2007) assessed the desiccation tolerance of seeds from six Eugenia native fruit species and demonstrated that seed drying hindered the formation of normal seedlings irrespective of the drying method used and that the lethal water level for these species was between 15 and $20 \%$.

The type of drying did not influence the emergence speed index, the maximum value of which was 0.349 after $33 \mathrm{~h}$ of drying. However, it decreased as the drying time progressed, demonstrating the negative effect of drying on the performance of the seeds (Figure 7). 
Figure 6. Emergence percentage of $E$. dysenterica DC. seedlings from seeds subjected to different drying periods. * Significant at $5 \%$ probability $(\mathrm{p}<0.05)$. Bar: Mean standard error.

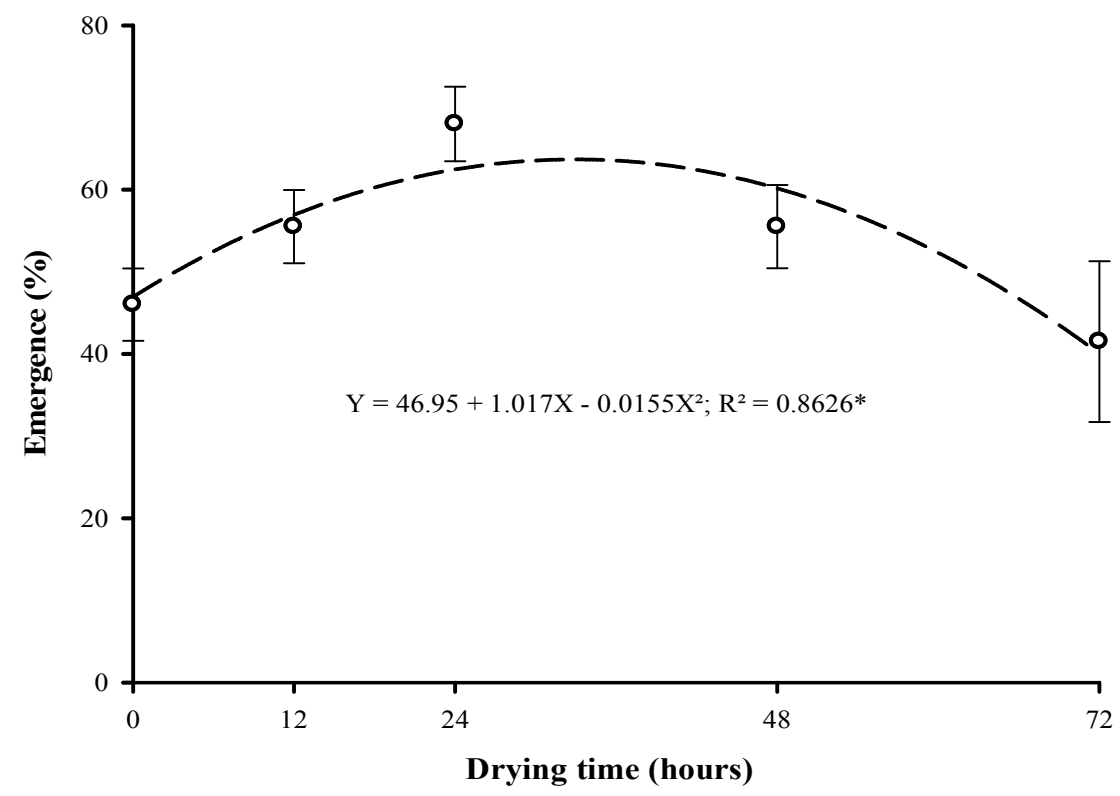

Figure 7. Emergence speed index (ESI) of E. dysenterica DC. seedlings from seeds subjected to different drying periods. * Significant at $5 \%$ probability $(\mathrm{p}<0.05)$. Bar: Mean standard error.

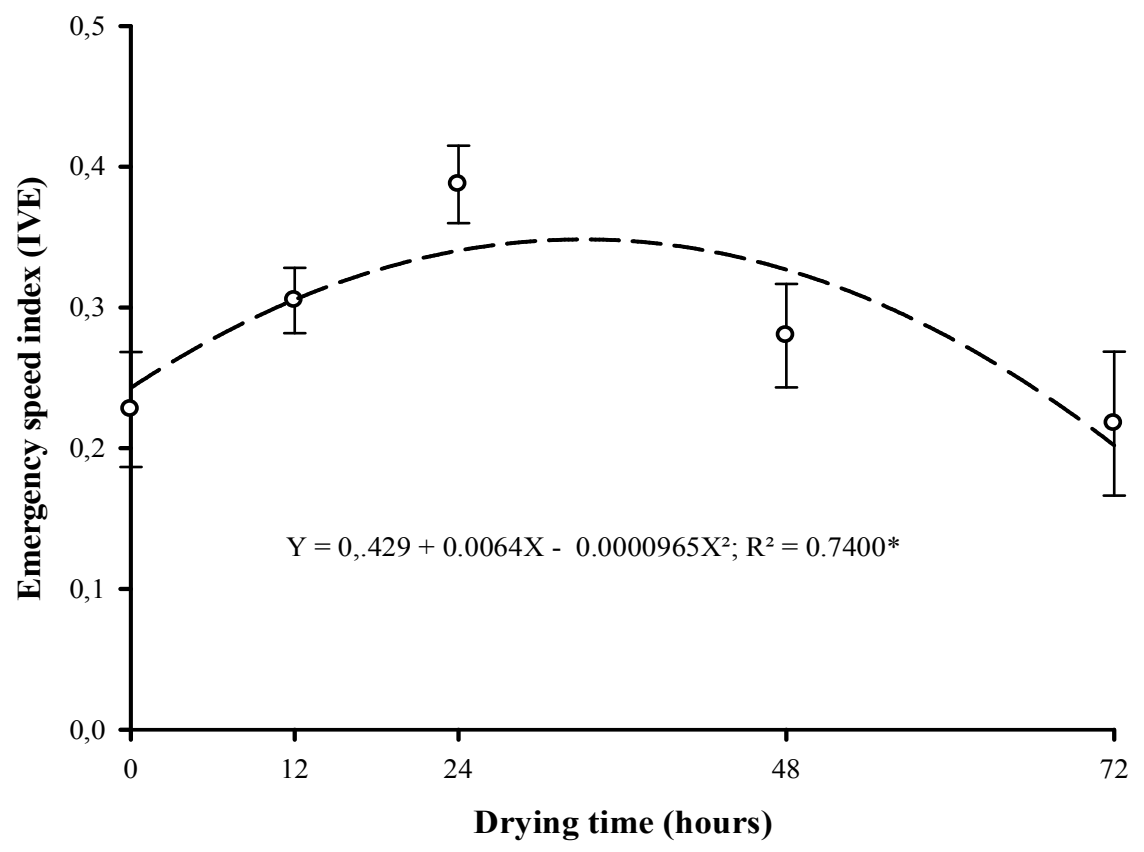


Similar results were observed in the mangabeira (Hancornia speciosa Gomes) seeds. They displayed maximum values of the emergence speed index after $21 \mathrm{~h}$ of drying, which sharply decreased after this period and reached zero value after $144 \mathrm{~h}$ (SANTOS et al., 2010). The seed germination rate was significantly reduced in the uvaia (Eugenia pyriformis Camb.) seeds subjected to drying at 35 ${ }^{\circ} \mathrm{C}$ for $72 \mathrm{~h}$ until $30 \%$ water content was achieved (JUSTO et al., 2007).
The type of drying did not affect the seedling length, since there was increase in this parameter up to the first $29 \mathrm{~h}$ of drying with a maximum value of $20.52 \mathrm{~cm}$, which decreased as the drying process progressed (Figure 8). The water content of the seeds subjected to drying for $29 \mathrm{~h}$ remained virtually unchanged in comparison to those with their initial water content. Therefore, the seed performance was not affected.

Figure 8. Length of $E$. dysenterica DC. seedlings from seeds subjected to different drying periods. * Significant at $5 \%$ probability $(\mathrm{p}<0.05)$. Bar: Mean standard error.

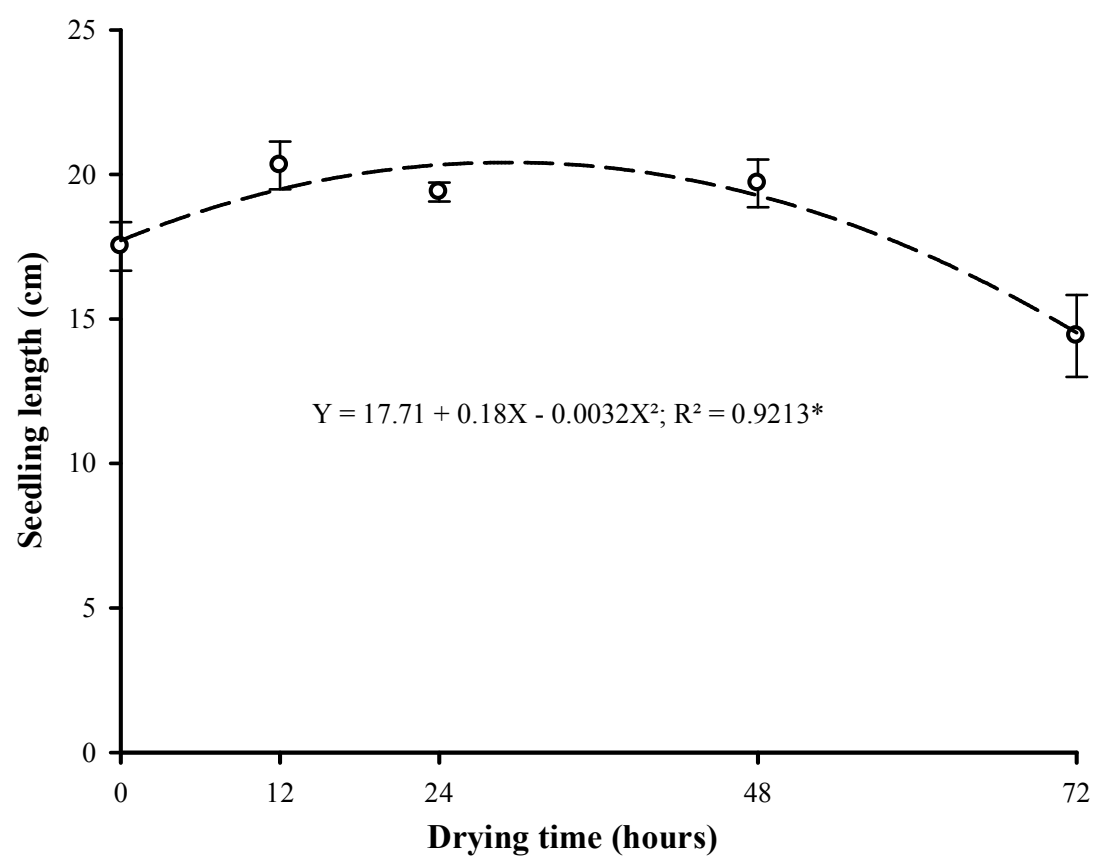

The drying of pitomba [Talisia esculenta (A. ST. Hil) Radlk] seeds for 38 and $40 \mathrm{~h}$ resulted in an increase in the seedling length in comparison to those with initial water content, and decreased as the drying process progressed (ALVES et al., 2008). The inga [Inga ingoides (Rich.) Willd.] seedlings exhibited maximum values of primary root length when seeds without the pulp were subjected to 15 $\mathrm{h}$ of drying. A linear decrease in the seedling shoot length was observed as the drying time increased (LAIME et al., 2011).

\begin{abstract}
Assay 3. Radiographic image analysis of $E$. dysenterica seeds subjected to drying

The radiographic image analysis exhibited an increase in the free space area existing between the embryo and the integument (embryo / embryo cavity), and a reduction in the embryonic area as the cagaita seed water content reduced from $47.8 \%$ to $23 \%$ (Figure 9).
\end{abstract}


Figure 9. Percentage of free area within E. dysenterica DC. seeds subjected to drying. * Significant at 5\% probability $(\mathrm{p}<0.05)$.

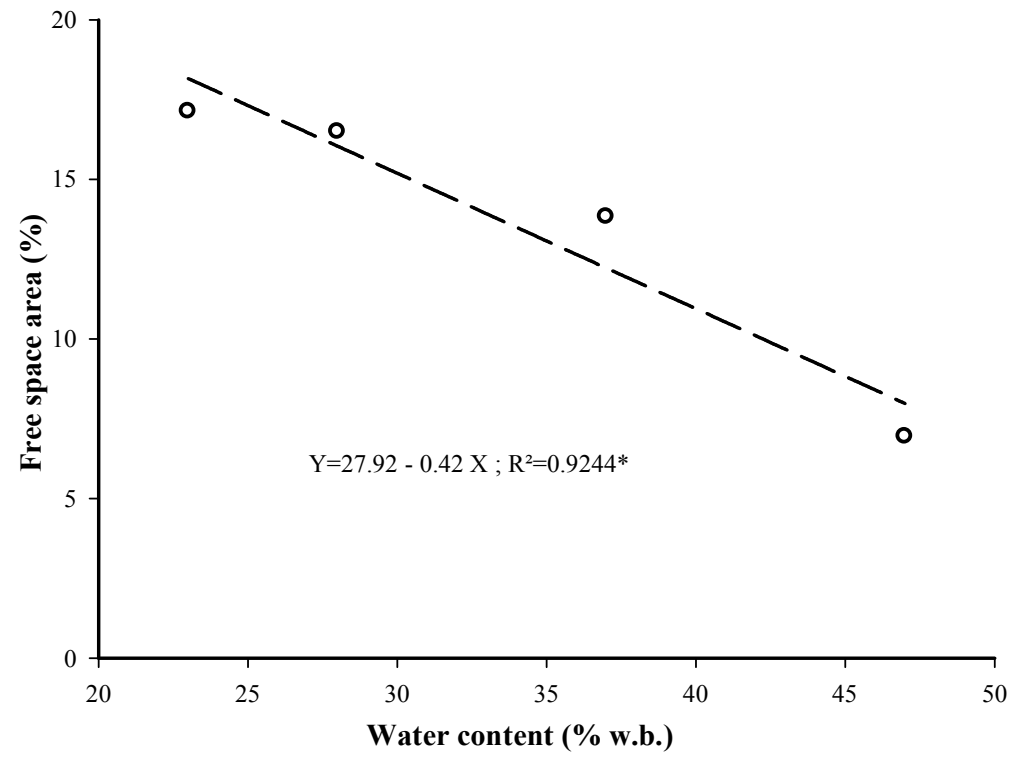

The evaluation of the seed integrity and internal morphology by means of the X-ray test displayed morphological changes in the endosperm as a result of the drying process. The reduction in the area occupied by the embryo within the seed resulted from compression during the drying process (Figure 10).

Figure 10. Radiographic images of $E$. dysenterica DC. seeds with different water contents. Arrows: Free space area (integument / endosperm).

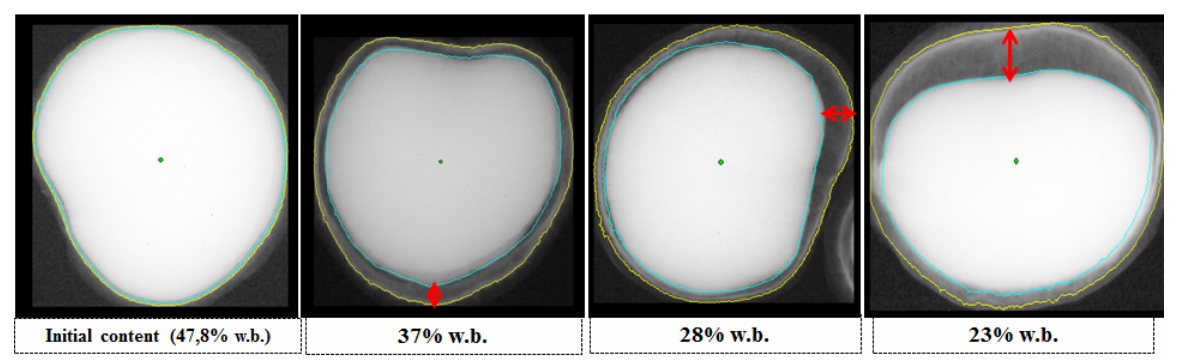

Silva et al. (2014) studied the curriola [Pouteria ramiflora (Mart.) Radlk.] seeds during the two maturation stages and with different water contents and obtained similar result. According to these results, a reduction in the area occupied by the embryo and an increase in the free space area within the seed were observed when the green seeds were subjected to drying up to $12 \%$ w.b.
In addition to the reduction in the area occupied by the embryo, the images obtained from the $\mathrm{X}$-ray test analysis allowed the identification of the mechanical damages (cracks) in the seeds subjected to drying (Figure 11). These damages compromised the seed vigor and seedling development. Thus, the image analysis appears to be a useful tool to identify the damages within the seeds and to determine the effects of drying as it complements the results obtained by means of the physiological analysis. 
Figure 11. Mechanical damage to the endosperm of $E$. dysenterica DC. seed subjected to drying up to $20 \%$ water content (w.b.).

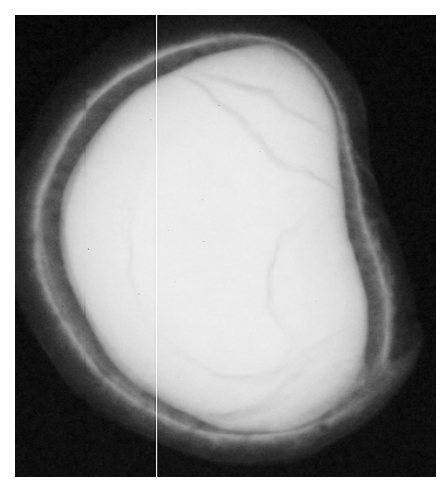

The morphological condition of the seeds, which was obtained through images of the seeds internal structures exhibited a cumulative result of all the factors that influence the loss of viability and the damages accumulated during the drying process, especially in the recalcitrant seeds (GOODMAN et al., 2005). In addition, according to Dell'Aquila
(2007), the free space area might be considered an indicator of the germination potential, which is related to the increase of abnormal seedlings.

The maximum emergence percentage value $(88 \%)$ was observed in the seeds with initial water content and it decreased as the drying process progressed (Figure 12).

It was possible to establish a direct relationship between the increased free area within the seed cavity and seedling emergence. A significant negative correlation $(r=-0.8797)$ was observed between the free space area and seedling emergence. Thus, the higher the free space area within the seed the lower is the seedling emergence percentage (Figure 13).

Drying resulted in a reduced embryo area within the seed, and consequently, in reduced seedling vigor and performance. The radiographic image analysis confirmed the negative effect of drying on the physiological performance of E. dysenterica seeds, thus reaffirming their recalcitrance.

Figure 12. Emergence percentage of E. dysenterica DC. seedlings from seeds subjected to drying. * Significant at $5 \%$ probability $(\mathrm{p}<0.05)$.

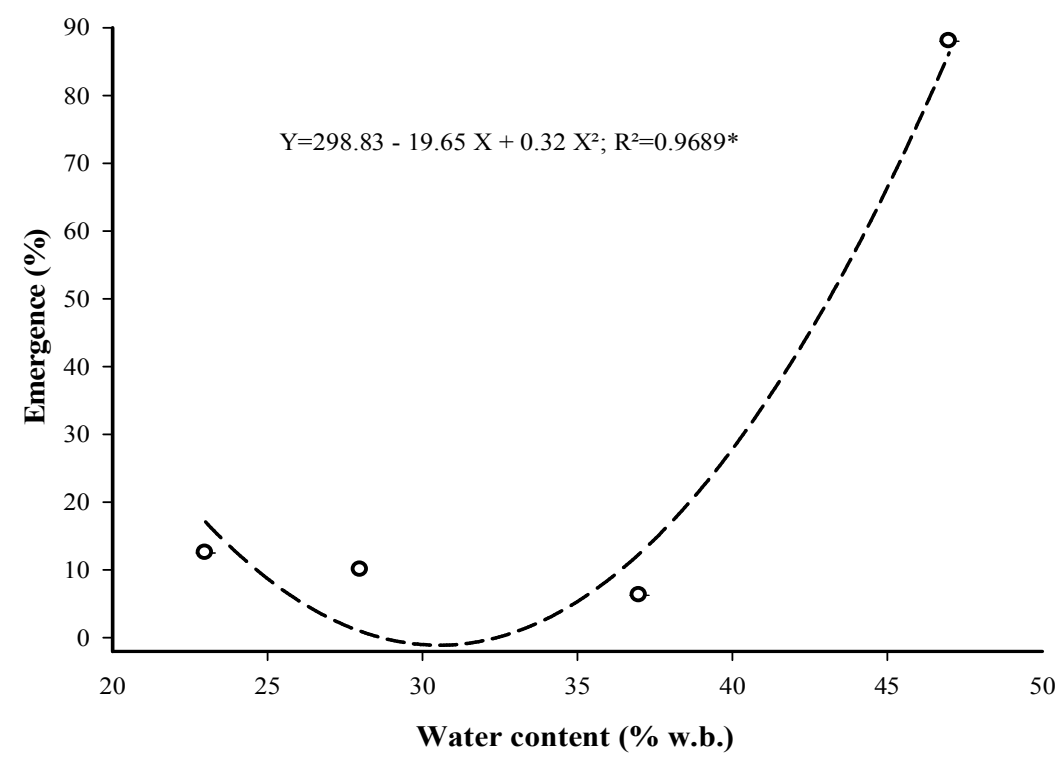


Figure 13. Correlation between the free space area and the emergence percentage of $E$. dysenterica DC. seedlings from seeds subjected to drying. $(\mathrm{r}=-0.8797)$.

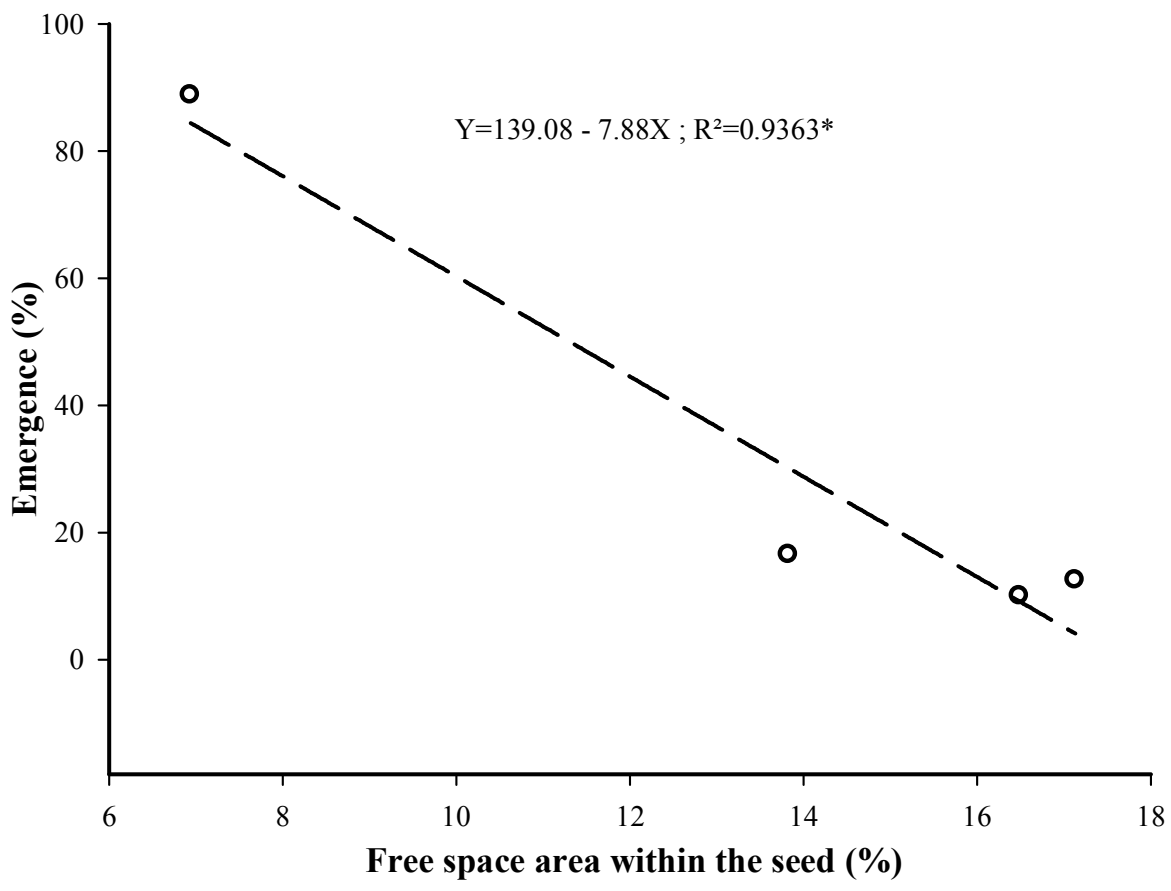

\section{Conclusions}

E. dysenterica seeds exhibited the classical triphasic pattern of water absorption with rapid weight gain during the first $60 \mathrm{~h}$ of imbibition and germination of $94.4 \%$ for the $192 \mathrm{~h}$.

The drying process, regardless of the type, negatively influenced the E. dysenterica seed, reaffirming the recalcitrant feature of the seeds of this species.

E. dysenterica seeds do not tolerate drying periods longer than $24 \mathrm{~h}$ and should be sown immediately after collection.

The analysis of the radiographic images obtained in the X-ray test enabled the establishment of a direct between the increase in the free space area within the seed and decrease in the emergence of seedlings.

\section{Acknowledgements}

The authors acknowledge the financial support of CNPq-CAPES for granting the scholarship of the first author.

\section{References}

ALVES, E. U.; SILVA, K. B.; BRUNO, R. L. A.; ALVES, A. U.; CARDOSO, E. A.; GONÇALVES, E P.; BRAZ, M. S. S. Comportamento fisiológico de sementes de pitombeira [Talisia esculenta (A. ST. Hil) Radlk] submetidas à desidratação. Revista Brasileira de Fruticultura, Jaboticabal, v. 30, n. 2, p. 509-516, 2008.

AMARA, I.; ODENA, A.; OLIVEIRA, E.; MORENO, A.; MASMOUDI, K.; PAGÉS, M.; GODAY, A. Insights into maize LEA proteins: from proteomics to functional approaches. Plant and Cell Physiology, Oxford, v. 53, n. 2, p. 312-329, 2012.

ANDRADE, A. C. S.; CUNHA, R.; SOUZA, A. F.; REIS, R. B.; ALMEIDA, K. L. Physiological and morphological aspects of seed viability of a neotropical savannah tree, Eugenia dysenterica DC. Seed Science and Technology, International Seed Testing Association- zurich, v. 31, n. 1, p. 125-137, 2003. 
BARTELS, D. Desiccation tolerance studied in the resurrection plant Craterostigma plantagineum. Integrative and Comparative Biology, Oxford, v. 45, n. 5, p. 696-701. 2005.

BERJAK, P.; PAMMENTER, N. W. Implications of the lack of desiccation tolerance in recalcitrant seeds. Frontiers in Plant Science, Lausanne, v. 4, n. 478, p. 1-9, 2013.

BINO, R. J.; AARTSE, J. W.; BURG, W. J. Nondestructive X-ray of Arabidopsis embryo mutants. Seed Science Research, Cambridge, v. 3, n. 3, p. 167-170, 1993.

BOUDET, J.; BUITINK, J.; HOEKSTRA, F. A.; ROGNIAUX, H.; LARRÉ, C.; SATOUR, P.; LEPRINCE, O. Comparative analysis of the heat stable proteome of radicles of Medicago truncatula seeds during germination identifies late embryogenesis abundant proteins associated with desiccation tolerance. Plant Physiology, 140, n. 4, p. 1418-1436, 2006.

BRASIL. Ministério da Agricultura, Pecuária e Abastecimento. Regras para análise de sementes. Ministério da Agricultura, Pecuária e Abastecimento. Secretaria de Defesa Agropecuária. Brasília, DF: Mapa/ ACS, 2009. $395 \mathrm{p}$.

CAMILO, Y. M. V.; SOUZA, E. R. B.; VERA, R.; NAVES, R. V. Caracterização de frutos e seleção de progênies de cagaiteiras (Eugenia dysenterica DC.). Cientifica, Jaboticabal, v. 42, n. 1, p. 1-10, 2014.

CARAMORI, S. S.; LIMA, S. C.; FERNANDES, K. F. Biochemical characterization of selected plant species from Brazilian Savannas. Brazilian Archives of Biology and Technology, Curitiba, v. 47, n. 2, p. 253-259, 2004.

CARVALHO, L. R.; CARVALHO, M. L. M.; DAVIDE, A. C. Utilização do teste de raios-X na avaliação da qualidade de sementes de espécies florestais de Lauraceae. Revista Brasileira de Sementes, Londrina, v. 31, n. 4, p. 57-66, 2009.

COMIN, A.; PEREIRA, L.; MACIEL, C. G.; CHIES, J.; MUNIZ, M. F. B. Secagem e armazenamento de sementes de Eugenia uniflora L. Revista Brasileira de Ciências Agrárias, Recife, v. 9, n. 1, p. 84-90, 2014.

CRISPIM, J. E.; MARTINS, J. C.; PIRES, J. C.; ROSOLEM, C. A.; CAVARIANI, C. Determinação da taxa de respiração em sementes de soja pelo método da titulação. Pesquisa Agropecuária Brasileira, Brasília, v. 29, n. 10, p. 1517-1521, 1994.

DANTAS, B. F.; CORREIA, J. S.; MARINHO, L. B.; ARAGÃO, C. A. Alterações bioquímicas durante a embebição de sementes de catingueira (Caesalpinia pyramidalis Tul.). Revista Brasileira de Sementes, Londrina, v. 30, n. 1, p. 221-227, 2008a.

DANTAS, B. F.; SOARES, F. S. J.; LÚCIO, A. A.; ARAGÃO, C. A. Alterações bioquímicas durante a embebição de sementes de baraúna (Schinopsis brasiliensis engl.). Revista Brasileira de Sementes, Londrina, v. 30, n. 2, p. 214-219, 2008 b.

DELAHAIE, J.; HUNDERTMARK, M.; BOVE, J.; LEPRINCE, O.; ROGNIAUX, H.; BUITINK, J. LEA polypeptide profiling of recalcitrant and orthodox legume seeds reveals ABI3-regulated LEA protein abundance linked to desiccation tolerance. Journal of Experimental Botany, Oxford, v. 64, n. 14, p. 4559-4573, 2013.

DELGADO, L. F.; BARBEDO, C. J. Tolerância à dessecação de sementes de espécies de Eugenia. Pesquisa Agropecuária Brasileira, Brasília, v. 42, n. 2, p. 265-272, 2007.

DELL'AQUILA, A. Pepper seed germination assessed by combined X-radiography and computer-aided imaging analysis. Biologia Plantarum, Praga, v. 51, n. 4, p. $777-$ 781, 2007.

FARRANT, J. M.; PAMMENTER, N. W.; BERJAK, P. Recalcitrance: a current assessment. Seed Science and Technology, International Seed Testing AssociationZurich, v. 16, n. 1, p. 155-166, 1988.

FERNANDES, M. R.; BARBOZA, M. P.; SOUZALEAL, T.; PEDROSO-DE-MORAES, C. Morfobiometria carpo-seminal e germinação de Lafoensia pacari A. St. Hil. (Lythraceae) exposta a diferentes concentrações de $\mathrm{GA}_{3}$. Semina. Ciências Agrárias, Londrina, v. 33, n. 6, p. 2571-2584, 2012. Suplemento 1.

FERREIRA, D. F. Sistema de análise estatística SISVAR. versão 4.6 (build 61) software. Lavras: UFLA, 2003.

GOLOVINA, E. A.; VAN, A. S. H.; HOEKSTRA, F. A. Membrane chemical stability and seed longevity. European Biophysic Journal, Heidelberg, v. 39, n. 4, p. 657-668, 2010.

GOODMAN, R. C.; JACOBS, D. F.; KARRFALT, R. P. Evaluating desiccation sensitivity of Quercus rubra acorns using X-ray image analysis. Canadian Journal of Forest Research, Ottawa, v. 35, n. 12, p. 2823-2831, 2005.

GUSMÃO, E.; VIEIRA, F. A.; FONSECA, E. M. Biometria de frutos e endocarpos de murici (Byrsonima verbascifolia Rich. Ex. A. Juss). Cerne, Lavras, v. 12, n. 1, p. 84-91, 2006. 
JUSTO, C. F.; ALVARENGA, A. A.; ALVES, E.; GUIMARÃES, R. M.; STRASSBURG, R. C. Efeito da secagem, do armazenamento e da germinação sobre a micromorfologia de sementes de Eugenia pyriformis Camb. Acta Botanica Brasilica, Belo Horizonte, v. 21, n. 3, p. 539-551, 2007.

KLINK, C. A.; MACHADO, R. B. A conservação do Cerrado brasileiro. Megadiversidade, Belo Horizonte, v. 1, n. 1, p. 147-155, 2005.

LAIME, E. M. O.; OLIVEIRA, D. C. S.; ALVES, E. U.; GUEDES, R. S. Emergência e crescimento inicial de plântulas de Inga ingoides (RICH.) WILLD. em função da secagem das sementes. Engenharia Ambiental: Pesquisa e Tecnologia, Espírito Santo do Pinhal, v. 8, n. 3, p. 237-250, 2011.

MACHADO, C. F.; CICERO, S. M. Aroeira-branca [Lithraea molleoides (Vell.) Engl. - Anacardiaceae] seed quality evaluation by the X-ray test. Scientia Agricola, Piracicaba, v. 60, n. 2, p. 393-397, 2003.

MAGUIRE, J. D. Speed of germination aid in selection and evaluation for seedling emergence and vigor. Crop Science, Madison, v. 2, p. 176-177, 1962.

MARCOS FILHO, J.; GOMES JUNIOR, F. G.; BENNETT, M. A.; WELLS, A. A.; STIEVE, S. Using Tomato Analyzer software to determine embryo size in $\mathrm{X}$-rayed seeds. Revista Brasileira de Sementes, Londrina, v. 32, n. 2, p. 146-153, 2010.

MARTINOTTO, C.; PAIVA, R.; SOARES, F. P.; SANTOS, B. R.; NOGUEIRA, R. C. Cagaiteira (Eugenia dysenterica DC.). Lavras: [s.n.], 2008. 21 p. (Boletim técnico, 78).

MASETTO, T. E.; DAVIDE, A. C.; SILVA, E. A. A.; FARIA, J. M. R. Avaliação da qualidade de sementes de Eugenia pleurantha (Mytaceae) pelo teste de raios X. Revista Brasileira de Sementes, Londrina, v. 29, n. 3, p. 170-174, 2007.

OLIVEIRA, C. F.; OLIVEIRA, D. C.; PARISI, J. J. D.; BARBEDO, C. J. Deterioração de sementes de espécies brasileiras de Eugenia em função da incidência e do controle de fungos. Revista Brasileira de Sementes, Londrina, v. 33, n. 3 p. 520-532, 2011.
PAMMENTER, N. W.; BERJAK, P. Aspects of recalcitrant seed physiology. Revista Brasileira de Fisiologia Vegetal, Brasília, v. 12, p. 56-69, 2000. Edição Especial.

RADWAN, A.; HARA, M.; KLEINWÄCHTER, M.; SELMAR, D. Dehydrin expression in seeds and maturation drying: a paradigm change. Plant Biology, v. 16, n. 5, p. 853-855, 2014.

SANTOS, C. R.; MENEZES, N. L.; VILLELA, F. A. Modificações fisiológicas e bioquímicas em sementes de feijão no armazenamento. Revista Brasileira de Sementes, Londrina, v. 27, n. 1, p. 104-114, 2005.

SANTOS, P. C. G.; ALVES, E. U.; GUEDES, R. S.; SILVA, K. B.; CARDOSO, E. A.; LIMA, C. R. Qualidade de sementes de Hancornia speciosa Gomes em função do tempo de secagem. Semina: Ciências Agrárias, Londrina, v. 31, n. 2, p. 343-352, 2010.

SILVA, L. A.; SALES, J. F.; OLIVEIRA, J. A.; SANTOS, H. O.; LARA, T. S.; SOARES, M. A. Physiological and biochemical performance of Pouteria ramiflora (Mart.) Radlk. seeds harvested at different maturation stages and subjected to drying. African Journal of Agricultural Research, Lagos, v. 9, n. 20, p. 1550-1559, 2014.

SILVA, R. S. M.; CHAVEZ, L. J.; NAVES, R. V. Caracterização de frutos e árvores de cagaita (Eugenia dysenterica DC.) no sudeste do estado de Goiás, Brasil. Revista Brasileira de Fruticultura, Jaboticabal, v. 23, n. 2, p. 330-334, 2001.

VIEIRA, R. D. Teste de condutividade elétrica. In: VIEIRA, R. D.; CARVALHO, N. M. Testes de vigor em sementes. Jaboticabal: FUNEP, 1994. p. 103-132.

VIEIRA, R. F.; AGOSTINI-COSTA, T. D. S.; SILVA, D. B.; SANO, S. M.; FERREIRA, F. R. Frutas nativas da região Centro-Oeste do Brasil. Brasília: Embrapa Informações Tecnológicas, 2010. 322 p. 